\title{
Hypoglossia-hypodactyly syndrome
}

INSERM

\section{Source}

INSERM. (1999). Orphanet: an online rare disease and orphan drug data base.

Hypoglossia-hypodactyly syndrome. ORPHA:989

Aglossia adactylia is characterized by the association of aglossia (absence of tongue), adactylia (absence of fingers or toes) and limb, craniofacial and other, less frequent malformations. 